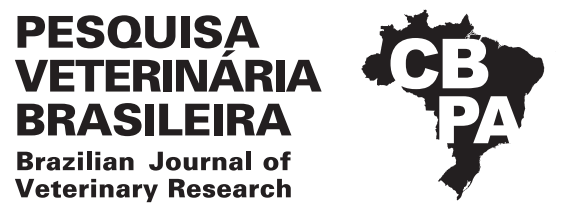

Pesq. Vet. Bras. 39(8):592-599, August 2019 DOI: 10.1590/1678-5150-PVB-6031

Original Article

ISSN 0100-736X (Print) Livestock Diseases

ISSN 1678-5150 (Online)

\title{
Campylobacter jejuni and Campylobacter coli originated from chicken carcasses modulate their transcriptome to translate virulence genes in human cells ${ }^{1}$
}

\author{
Roberta T. Melo* (D), Eliane P. Mendonça² (D), Edson C.Valadares Júnior², \\ Guilherme P. Monteiro ${ }^{2}$, Phelipe A.B.M. Peres ${ }^{2}$ and Daise A. Rossi ${ }^{2}$
}

\begin{abstract}
Melo R.T., Mendonça E.P., Valadares Júnior E.C., Monteiro G.P., Peres P.A.B.M. \& Rossi D.A. 2019. Campylobacter jejuni and Campylobacter coli originated from chicken carcasses modulate their transcriptome to translate virulence genes in human cells. Pesquisa Veterinária Brasileira 39(8):592-599. Laboratório de Epidemiologia Molecular, Faculdade de Medicina Veterinária, Universidade Federal de Uberlândia, Rua Ceará s/n, Bloco 2D, Sala 43, Bairro Umuarama, Uberlândia, MG 38402-018, Brazil. E-mail: roberta-melo@hotmail.com

The aim was to determine the spread of genetically similar profiles of Campylobacter in chicken carcasses and evaluate their ability to produce transcripts for ciaB, dnaJ, $p 19$ and $\operatorname{sod} B$ genes, before and after cultivation in Caco-2 cells. The strains used were isolated from 420 samples of chicken carcasses chilled and frozen ready for marketing. The species were identified by PCR-multiplex, the phylogeny was determined by RAPD-PCR and the presence of transcripts was performed by RT-PCR. We identified 74 (17.6\%) of Campylobacter strains, being $55(74.3 \%)$ C. jejuni and 19 (25.7\%) C. coli. The phylogenetic relationship demonstrated heterogeneity between isolates of the same species, with absence of clones, indicating the high level of diversity of circulating genotypes. The gene transcription showed conflicting results before and after the culture in Caco-2 cell, so that before cultivation isolates showed greater capacity to transcribe genes related to survival and after the interaction with human cells, the strains showed higher potential to transcribe genes associated with virulence. The result of this study contributes to the understanding of how these seemingly fragile microorganisms are the most prevalent bacterial agents in human gastroenteritis.
\end{abstract}

INDEX-TERMS: Campylobacter jejuni, Campylobacter coli, chicken, carcasses, transcriptome, virulence genes, human cells, campylobacteriosis, RT-PCR, gene, cells, virulence.

\begin{abstract}
RESUMO.- [Campylobacter jejuni e Campylobacter coli originadas de carcaças de frango modulam seu transcriptoma para traduzir genes de virulência em células humanas.] 0 objetivo foi determinar a disseminação de perfis geneticamente semelhantes de Campylobacter em carcaças de frango e avaliar sua capacidade de produzir transcritos para os genes $c i a B, d n a J, p 19$ e $\operatorname{sodB}$, antes e após o cultivo em células Caco-2. As cepas utilizadas foram isoladas de 420 amostras de carcaças de frango resfriadas e congeladas prontas para comercialização. As espécies foram identificadas por PCR-multiplex, a filogenia foi determinada
\end{abstract}

\footnotetext{
${ }^{1}$ Received on February 13, 2019.

Accepted for publication on March 31, 2019.

${ }^{2}$ Laboratório de Epidemiologia Molecular, Faculdade de Medicina Veterinária, Universidade Federal de Uberlândia (UFU), Rua Ceará s/n, Bloco 2D, Sala 43, Bairro Umuarama, Uberlândia, MG 38402-018, Brazil. Fone: +55 34 3213-2319. E-mails: daise.rossi@ufu.br, eliane_vet@yahoo.com.br, edson2campos@hotmail.com, guil.paz@hotmail.com, lipe-peres1@hotmail.com; *Corresponding author: roberta-melo@hotmail.com
}

por RAPD-PCR e a presença de transcritos foi realizada por RT-PCR. Identificamos 74 (17,6\%) das cepas de Campylobacter, sendo 55 (74,3\%) C. jejuni e 19 (25,7\%) C. coli. A relação filogenética demonstrou heterogeneidade entre isolados da mesma espécie, com ausência de clones, indicando o alto nível de diversidade dos genótipos circulantes. A transcrição gênica mostrou resultados conflitantes antes e após a cultura em células Caco-2, de modo que, antes do cultivo, os isolados apresentaram maior capacidade de transcrever genes relacionados à sobrevivência e após a interação com células humanas, as linhagens apresentaram maior potencial para transcrever genes associados à virulência. 0 resultado deste estudo contribui para a compreensão de como esses microrganismos aparentemente frágeis são os agentes bacterianos mais prevalentes na gastroenterite humana.

TERMOS DE INDEXAÇÃO: Campylobacter jejuni, Campylobacter coli, carcaças de frango, transcriptoma, genes de virulência, células humanas, campilobacteriose, RT-PCR, virulência. 


\section{INTRODUCTION}

Campylobacter spp. is the main zoonotic agent that causes gastroenteritis in developed countries (CDC 2013, WHO 2013, EFSA 2014). Campylobacteriosis has serious repercussions for public health and a significant socio-economic impact (EFSA 2013). The species most involved in diarrheal cases are Campylobacter jejuni and Campylobacter coli, being C. jejuni the most prevalent and more associated with autoimmune complications such as Guillain-Barré Syndrome (EFSA 2014).

Among the foods involved in Campylobacter transmission to humans, chicken meat and its derivatives are considered the main source (EFSA 2014). Data from the European Union countries and USA show contamination rate in chicken carcasses at high rates, ranging from 25 to $100 \%$ (CDC 2013, EFSA 2014).

Unlike other enterobacteria such as Salmonella and Shigella, this microorganism presents a series of signal transduction systems which may contribute to its adaptation to various stress conditions. These systems also help in gene expression related to virulence (Mourik 2011), as ciaB genes (intracellular invasion), dnaJ (thermotolerance), p19 (iron transport during stress) and $\operatorname{sod} B$ (defense to oxidative stress).

This study aimed to identify the positivity of Campylobacter $s p$. in chicken carcasses to determine the genetic proximity profiles of isolated and changes in the transcriptome of these agents when isolated from food and after passage in human intestinal cells (in vitro).

\section{MATERIALS AND METHODS}

We performed 21 collections of chilled and frozen chicken carcasses in the period of June 2011 to February 2012. In each collection were sampled 20 carcasses produced and slaughtered in three Brazilian states (Distrito Federal, Goiás and Minas Gerais), totaling 420 samples. The chicken carcasses were from refrigerators under federal inspection whose products are marketed across the country and also exported to Asia, Africa and the Middle East.

The processing of the samples was conducted at the Laboratory of Molecular Epidemiology at the Faculty of Veterinary Medicine and at the Center of Electron Microscopy of the Institute of Biomedical Sciences of "Universidade Federal de Uberlândia" (UFU). To perform all analyzes, it was used as positive control strains of Campylobacter jejuni ATCC 33291, C. coli ATCC 43478 and C. jejuni NCTC 11351, and milli-Q water in place of the sample as a negative control.

For isolation of Campylobacter spp., 420 chicken carcasses were subjected to rinsing process in $400 \mathrm{~mL}$ of $0.1 \%$ of casein peptone (Difco ${ }^{\circledR}$ ), as described by Zhao et al. (2010). A $30 \mathrm{~mL}$ portion of the product washings were pre-enriched in Bolton broth $\left(\mathrm{Oxoid}^{\circledR}\right)$ in double concentration and supplemented with antibiotics (Oxoid ${ }^{\circledR}$ ) and $5 \%$ of defibrinated sheep blood (Laborclin ${ }^{\circledR}$ ). The samples were incubated at $37^{\circ} \mathrm{C}$ for $44 \pm 4$ hours in microaerophilic atmosphere. After this time, $100 \mathrm{~mL}$ of each sample was inoculated on agar plates of m-CCDA (Campylobacter Blood-Free Selective Medium - Modified CCDA Preston) $\left(\right.$ Oxoid $^{\circledR}$ ) containing their antibiotic supplement $\left(\mathrm{Oxoid}^{\circledR}\right)$ and a membrane filter with porosity of $0,65 \mu \mathrm{m}$ (Millipore ${ }^{\circledR}$ ) to reduce contamination. Then the plates were incubated at $37^{\circ} \mathrm{C}$ for $44 \pm 4$ hours in microaerophilic atmosphere according to the instructions of ISO 10272-1 (ISO 2006).

The identification of $C$. jejuni and $C$. coli were verified by PCR-multiplex, with use of primers $p g 3$ (5'GAACTTGAACCGATTTG3')/pg50 (5'ATGGGATTTCGTATTAAC3') and $C 1$ (5'CAAATAAAGTTAGAGGTAGAATGT3') / $C 4$ (5'GGATAAGCACTAGCTAGCTGAT3'). DNA extraction was performed with DuPont ${ }^{\mathrm{TM}}$ PCR Reagent kit, according to the manufacturer's instructions. The primers, the PCR reagents concentrations and the amplification protocol were performed as Harmon et al. (1997).

After identifying, the strains were evaluated for the ability to produce transcripts. For this, RNA extraction was performed using the Trizol method as Li et al. (2008) with modifications. The isolates from each sample obtained from the four cropping agar plates of $\mathrm{m}$-CCDA, were transferred to microcentrifuge tubes containing $2 \mathrm{~mL}$ of $\mathrm{NaCl}$ solution $0.85 \%$ (Synth $^{\circledR}$ ). The mixture was centrifuged at $12,000 \mathrm{G}$ for ten minutes at $4^{\circ} \mathrm{C}$. To the obtained pellets was added $1 \mathrm{~mL}$ of Trizol (Invitrogen ${ }^{\circledR}$ ) and homogenized by vortexing (Phoenix ${ }^{\circledR}$ ). Thereafter, $200 \mu \mathrm{L}$ of chloroform was added (Isofar ${ }^{\circledR}$ ) and repeated the procedure of vortex homogenization followed by centrifugation at $12,000 \mathrm{G}$ for 15 minutes at $4^{\circ} \mathrm{C}$. The formed aqueous portion was transferred to a new microtube, to which $500 \mu \mathrm{L}$ of isopropanol was added (Sigma Aldrich ${ }^{\circledR}$ ), homogenized and centrifuged again at $12,000 \mathrm{G}$ for 10 minutes at $4^{\circ} \mathrm{C}$. At the pellet formed was added $1 \mathrm{~mL}$ of ethanol $75 \%$ (Sigma Aldrich ${ }^{\circledR}$ ) and after, homogenization and centrifugation at $7.500 \mathrm{~g}$ at $4^{\circ} \mathrm{C}$ for 5 minutes, the obtained supernatant was discarded. The RNA pellets were dried at room temperature to be diluted in $20 \mu \mathrm{L}$ of DEPC water (Invitrogen ${ }^{\circledR}$ ). The concentration of RNA used was $200 \mathrm{ng} / \mu \mathrm{L}$, quantified in a spectrophotometer device NanoDrop (Thermo Scientific ${ }^{\circledR}$ ).

Reverse transcription was performed with $10 \mathrm{U}$ of RNase inhibitor, 40U of MMLV-RT (Amersham Biosciences ${ }^{\circledR}$ ), 1X of MMLV-RT buffer (Amersham Biosciences ${ }^{\circledR}$ ), $200 \mu \mathrm{M}$ of dNTPs (dGTP, dATP, dTTP and dCTP), 126pmol of random hexamer oligonucleotides as primers (Invitrogen), $20 \mu \mathrm{L}$ of DEPC water (Invitrogen ${ }^{\circledR}$ ) and $1 \mu \mathrm{L}$ of RNA, all kept at $37^{\circ} \mathrm{C}$ for one hour to obtain complementary DNA (cDNA). Subsequently, $3 \mu \mathrm{L}$ of the cDNA was used for amplification in a reaction volume of $25 \mu \mathrm{L}$, comprising: $0,625 \mathrm{U}$ of Taq DNA polymerase, $5 \mathrm{mM}$ $\mathrm{MgCl}_{2}, 200 \mu \mathrm{M}$ of dNTPs and 4 pmoles of each primer (Table 1) (Invitrogen). The amplification and electrophoresis were performed as Birk et al. (2012).

The evaluation of gene transcription was also performed after culture in Caco- 2 cells (human colon adenocarcinoma cells of the cell bank of Rio de Janeiro, Brazil - BCRJ: CR069), to compare the change in behavior of the strains. Polarized Caco-2 cells grown in the bottles (BD Falcon ${ }^{\mathrm{TM}}$ ) were used to evaluation with 24 hours after inoculation (Pinto et al. 1983). For infection, an aliquot of $100 \mathrm{~mL}$ of $\mathrm{NaCl} 0.85 \%$ solution containing $10^{6} \mathrm{CFU}$ of each strain was placed in a bottle (BD Falcon ${ }^{\mathrm{TM}}$ ) with approximately $80 \%$ of confluency, containing $5 \mathrm{~mL}$ of DMEM (Invitrogen) pure. After incubation, the cells inside of the bottle (BD Falcon ${ }^{\mathrm{TM}}$ ) were scraped with a cell scraper aid $\left(\mathrm{BD} \mathrm{Falcon}{ }^{\mathrm{TM}}\right.$ ) and the contents were transferred to microcentrifuge tubes of $2 \mathrm{~mL}$ containing DMEM medium (Invitrogen). The samples were centrifuged at $12,000 \mathrm{G}\left(\right.$ Cientec $\left.^{\circledR}\right)$ for ten minutes at $4^{\circ} \mathrm{C}$. To the pellet was added $1 \mathrm{~mL}$ of Trizol (Invitrogen ${ }^{\circledR}$ ) and the remaining steps for the realization of the RNA extraction and RT-PCR, were performed as described previously.

The genetic diversity of strains was determined by RAPD-PCR (Random Amplification of Polymorphic DNA), according to Akopyanz et al. (1992), using the primers HLWL (5'ACGTATCTGC3') and 1290 (5'GTGGATGCGA3'). Images of the gels were captured by transluminator (Loccus Biotechnology ${ }^{\circledR}$ ) for further computational analysis in the program GelCompar $\mathrm{II}^{\circledR}$. All formed bands were considered in the analysis and the similarity matrix was obtained using the Dice similarity coefficient. The final analysis was based on the average of the results obtained in both primers (average 
Table 1. Primers used to verify the production of transcripts for ciaB, dnaJ, p19 and sodB genes by Campylobacter jejuni and C. coli before and after cultivation in Caco-2 cells

\begin{tabular}{cccc}
\hline Genes & Sequence 5' $\rightarrow 3^{\prime}$ & Molecular weight (mw) & Reference \\
\hline \multirow{2}{*}{ cia } & ATATTTGCTAGCAGCGAAGAG & 157 & Li et al. (2008) \\
& GATGTCCACTTGTAAAGGTG & & Li et al. (2008) \\
& AGTGTCGAGCTTAATATCCC & 117 & Birk et al. (2012) \\
& GGCGATGATCTTAACATACA & 206 & Birk et al. (2012)
\end{tabular}

from experiments). It was used UPGMA (unweighted pair group method with arithmetic mean) for the construction of dendrograms (Madden et al. 2007).

The tests were performed in triplicate and the results were tabulated and submitted to descriptive statistics to calculate the percentages for Campylobacter occurrence and the species $C$. jejuni and $C$. coli. To analyze the production of transcripts in each species, at the time of isolation in food and after cultivation in Caco- 2 cells was used the Fisher one tailed exact test, by GraphPad Software Inc.

\section{RESULTS AND DISCUSSION}

Of 420 chickens' carcasses investigated, 74 (17.6\%) were positive for Campylobacter. Of these, 55/74 (74.3\%) were identify by multiplex PCR as Campylobacter jejuni and 19/74 (25.7\%) as C. coli.

Positivity was lower than that found in other studies, but the higher incidence of $C$. jejuni in this type of food agrees with the global data of the WHO (2013) and EFSA (2014). According to EFSA report (2014), overall, 23.6\% of individual samples or in flocks were positive for Campylobacter in 15 member states of the European Union in 2012. A study carried out in Ireland in 2008 showed that from 394 chicken cooled carcasses that were studied, $98 \%$ were contaminated with $C$. jejuni (EFSA 2010). In Canada, the percentage was $33.7 \%(2146 / 6367)$ of positive samples in cooled chicken meat from 2003 to 2010 (Agunos et al. 2013). In Iran, was $63 \%$ and in Japan 45.8\% (FAO 2009).

The analysis by RT-PCR showed the presence of transcripts in $62.0 \%(49 / 74)$ of the evaluated strains after isolation from carcasses, and before cultivation in Caco- 2 cells. Of this total, 69.4\% (34/49) treated up as genes transcribed by C. jejuni, and $30.6 \%$ (15/49) by $C$. coli. The studied genes showed different importance for virulence and adaptation processes of the strains to stress related to cold.

The potential pathogenic of Campylobacter can be identified by the presence of $c i a B$ and $d n a$ J genes. The gene $c i a B$ is essential to encode $\mathrm{CiaB}$ protein, which is important in the process of epithelial cell invasion (Poly \& Guerry 2008) and also the invasion of intestinal mucosa (Ziprin et al. 2001). The dnaJ gene encodes a heat shock protein, which guarantees thermotolerance, and thus the micro-organism is able to overcome to the abrupt temperature variations (Stintzi 2003), facilitating their adaptation to the conditions of human intestine.

The $p 19$ and $\operatorname{sod} B$ genes are associated with the cold adaptation mechanisms. The $p 19$ gene encodes a periplasmic iron-dependent protein whose function is to transport iron
(Palyada et al. 2004). The regulation of this protein indicates a way to control the level of intracellular iron during stress, a key element in the metabolic processes (Birk et al. 2012). The translation of SodB protein triggers a defense mechanism of the cell against oxidative stress resulting from the cold shock. In addition, this gene specifically protects the cellular components, including various cytoplasmic enzymes, DNA and membrane factors against damage caused by oxygen free radicals (Stintzi \& Whitworth 2003).

In this study, in $C$. jejuni, the transcription of ciaB gene occurred in $54.5 \%(30 / 55)$ of the strains, dnaJ gene in $40.0 \%$ $(22 / 55)$, p19 gene in $30.9 \%(17 / 55)$ and sodB gene in $25.4 \%$ $(14 / 55)$. For $C$. coli species, the values found were $31.6 \%$ (6/19), 26.3\% (5/19), 57.9\% (11/19) and 68.4\% (13/19), respectively, for the same genes (Table 2).

These data shows that, although strains isolated from samples kept under the same conditions (low temperatures), the species showed different behavior. Transcription of genes associated with virulence ( $c i a B$ and $d n a$ ) ) was most evident in C. jejuni, with significant difference in $\operatorname{cia} B(\mathrm{P}=0.04)$. In other hand, in $C$. coli was observed that, statistically, had a greater production of transcripts for genes related to cold shock stress $(p 19$ and $\operatorname{sod} B)(\mathrm{P}<0.01)$.

Therefore, it can be inferred that even when subjected to injury conditions, $C$. jejuni showed pathogenic potential associated with the invasion process and expressed in lower percentages the adaptive mechanisms to survive. According to Mourik (2011) the gene transcription in Campylobacter is regulated to prevent the unnecessary production.

The virulent profile of $C$. jejuni was quoted by Thakur et al. (2010) and Melo et al. (2013), showed that the greatest potential of this species over the other in causing clinical cases in humans (81.1\%) (EFSA 2014) is due to the properties of invasion, colonization and toxin production which are essential to elicit its pathogenesis.

In contrast, $C$. coli showed that its priority is to ensure the survival, through the consolidation of the P19 and SodB proteins. The expression of mechanisms of adaptation to low temperatures for $C$. coli allows the acquisition or the biosynthesis of cryoprotectant molecules, leading to changes in the lipid composition of the membrane ensuring the survival under these conditions (Stintzi \& Whitworth 2003).

After cultivation in Caco- 2 cells was observed that there was a change in the transcriptome of the strains. The transcription was observed in $90.5 \%(67 / 74)$ of the strains, whereas $82.1 \%$ (55/67) were produced by $C$. jejuni and $17.9 \%(12 / 67)$ by C. coli. 
Table 2. Production of transcripts of the ciaB, dnaJ, p19 and sodB genes by 74 Campylobacter strains isolated from chicken carcasses before and after culturing in Caco-2 cells

\begin{tabular}{|c|c|c|c|c|}
\hline \multirow[b]{2}{*}{ Gene transcription } & \multicolumn{2}{|c|}{ Beforeculture in Caco- 2 cells } & \multicolumn{2}{|c|}{ Afterculture in Caco-2 cells } \\
\hline & $\begin{array}{c}\text { C. jejuni }(\mathrm{N}=55) \\
\mathrm{n}(\%)\end{array}$ & $\begin{array}{c}\text { C. coli }(\mathrm{N}=19) \\
\mathrm{n}(\%)\end{array}$ & $\begin{array}{c}\text { C. jejuni }(\mathrm{N}=55) \\
\mathrm{n}(\%)\end{array}$ & $\begin{array}{c}\text { C. coli }(\mathrm{N}=19) \\
\mathrm{n}(\%)\end{array}$ \\
\hline $\operatorname{cia} B$ & $30(54,5)^{\mathrm{aA}}$ & $6(31,6)^{\mathrm{bC}}$ & $36(65,4)^{\mathrm{cA}}$ & $8(42,1)^{\mathrm{dC}}$ \\
\hline dnaJ & $22(40,0)^{\mathrm{aA}}$ & $5(26,3)^{\mathrm{aC}}$ & $42(76,4)^{\mathrm{cB}}$ & $10(52,6)^{\mathrm{dD}}$ \\
\hline p19 & $17(30,9)^{\mathrm{aA}}$ & $11(57,9)^{\mathrm{bc}}$ & $7(12,7)^{\mathrm{cB}}$ & $2(10,5)^{\mathrm{cD}}$ \\
\hline $\operatorname{sod} B$ & $14(25,4)^{\mathrm{aA}}$ & $13(68,4)^{\mathrm{bC}}$ & $0(0)^{\mathrm{cB}}$ & $3(15,8)^{\mathrm{dD}}$ \\
\hline
\end{tabular}

$\overline{\mathrm{N}}=$ number of evaluated strains, $\mathrm{n}=$ number of strains that transcribed, $\%=$ percentage of strains that transcribed, $\mathrm{a}, \mathrm{b}=$ difference between species before passing through Caco- 2 cells, c, $\mathrm{d}=$ difference between species after cultivation, $\mathrm{A}, \mathrm{B}=$ difference in transcription by $C$. jejuni before and after cultivation in cells, $\mathrm{C}, \mathrm{D}=$ difference in transcription by $C$. coli before and after the culture (one tailed Fisher Test $-\mathrm{P}<0.05$ ).

The transcripts' production were found in all 55 studied strains of $C$. jejuni, to $c i a B$ gene the occurrence was of $65.4 \%$ $(36 / 55)$ of the strains, to $d n a J$ was $76.4 \%(42 / 55)$ and to $p 19$ was $12.7 \%(7 / 55)$. There were no transcripts for sodB. To C. coli, the percentages were $42.1 \%(8 / 19), 52.6 \%(10 / 19), 10.5 \%$ $(2 / 19)$ and $15.8 \%(3 / 19)$ for the same genes, respectively (Table 2).

The modulation of gene transcription in this moment (after inoculation in Caco-2 cells) proves the fact that these microorganisms have highly sensitive and specific mechanisms for rapid adaptation and change in their behavior (Mourik 2011).

Ma et al. (2009) evaluated the virulence expression associated with the genes $c d t B$, $c a d F$ and $c i a B$, when $C$. jejuni was submitted to nutritional stress. The $c d t B$ transcription was observed only in the periods from 2 to 6 hours, while the expression of $c a d F$ and $c i a B$ had been significantly reduced between 24 to 48 hours under nutritional stress. Distinctively, exposure to zinc oxide ( $\mathrm{ZnO}$ ), a food additive, did not significantly affect the transcription of $c d t B, c a d F$ and ciaB (Xie et al. 2011).

It was observed a tendency to increase transcription of virulence genes ( $c i a B$ and $d n a)$ and decreased of cold adaptation genes ( $p 19$ and $\operatorname{sod} B$ ) when both species were cultured in Caco-2 cells. However, the change was not significant for ciaB gene. By species' comparison, it was observed that this behavior was more evident $(\mathrm{P}<0.05)$, with the exception of the $p 19$ gene, which showed no significant difference. This confirms the higher pathogenic potential of C. jejuni and a lower necessity for expressing characteristics of thermal adaption when compared to $C$. coli. These study verifies further evidence that $C$. jejuni has greater advantage over $C$. coli in causing clinical cases in humans.

This was expected, since according to Konkel et al. (2004) a greater transcription of genes associated with invasion occurs when the strains are in contact with the host intestinal epithelial cells. The presence of CiaB proteins increases the disease's severity with development of diarrhea symptoms 24 hours after contact, differently of strains with a lack of translation of these proteins that can carry this symptom only after three days of incubation (Konkel et al. 2001).

Moreover, the cultivation of the strains in higher temperature $\left(37^{\circ} \mathrm{C}\right)$ and appropriate environment $\left(5 \%\right.$ of $\left.\mathrm{CO}_{2}\right)$ in the presence of nutrients and host cells that enable the development of pathogenesis may have contributed to the expression of $\operatorname{cia} B$ and dnaJ genes.
It is important to emphasize that, although most studies give greater importance to $C$. jejuni pathogenic potential (Ma et al. 2009, Mourik 2011, Xie et al. 2011), it is essential to highlight merit also to C. coli (Di Giannatale et al. 2014) in the transcription of genes that enhance virulence-associated to the pathogenic potential when presented in a human host. The submission to the different conditions promoted variations in the transcriptome of these agents as a way to overcome the environment and adaptation to allow their survival and colonization.

The homology among isolates of both species not identified the presence of clones, but were detected clusters with genetic similarity greater than $80 \%$ and were classified as belonging to the same genotype (Fig.1 and 2).

Were identified 15 clusters in C.jejuni corresponding to A to 0 profiles and 18 distinct genotypes (Fig.1), which proves the high genetic diversity among 55 isolates. As for the place of isolation, it was found that the profiles D, E, J, K, L and O had strains originated from the same place, Minas Gerais. However, the most prevalent was the presence of strains' clusters from chickens of different places, in groups A, B, C, F, G, H, I, M and N. This indicates that there is dissemination of different genotypes between three regions studied, and probably for other states in the country, besides the different nations that import these products.

The comparison on the day of collection of the samples indicates that the profiles $\mathrm{B}, \mathrm{C}, \mathrm{G}, \mathrm{J}, \mathrm{K}, \mathrm{M}$ and $\mathrm{O}$ represents clusters of strains on the same day, and the groups J, K and $\mathrm{O}$ have isolated strains of the same flock. These three clusters infer the possibility of cross contamination in some stage of the production process, which promoted the presence of strains with high similarity in different chickens from the same flock. The other groups, A, D, E, F, H, I, L and N are composed of strains from different flocks, which suggest a possible neglection of biosecurity standards, which may have contributed to the persistence of the micro-organism along the production chain. This hypothesis can be sustained in the observation of cluster E, which has $84.8 \%$ of similarity, consisting of four strains from Minas Gerais chickens identified in September and November 2011 and in January and February 2012, confirming the persistence of genotype for at least six months.

As for genotypic characteristics related to gene transcription before and after cultivation in Caco-2 cells was observed homology to clusters B, D, E, G, I, L and $\mathrm{O}$ for the dnaJ gene and in clusters F, $\mathrm{H}$ and J to ciaB gene. Profiles A, C and N had in common the transcription of $c i a B$ and $d n a J$. The strains 


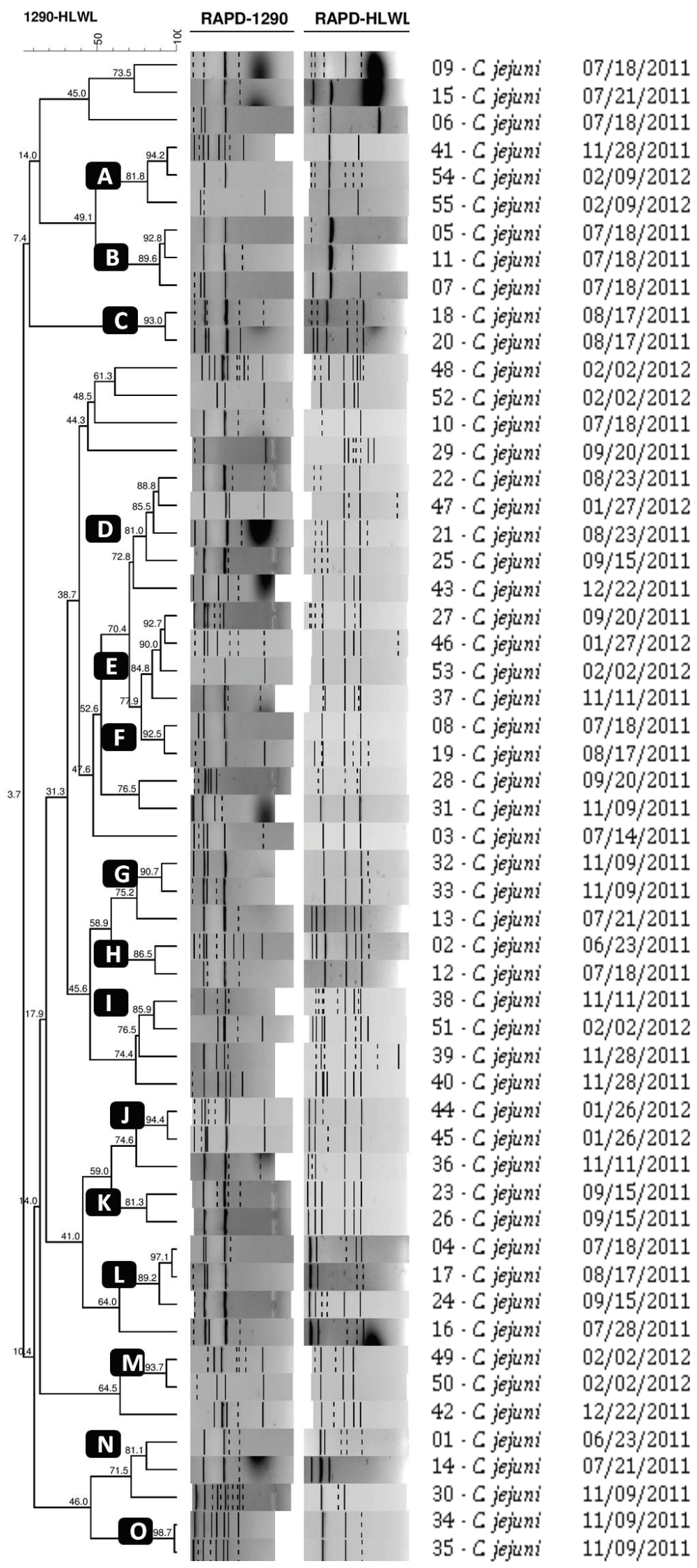

Fig.1. Dendrogram of 55 Campylobacter jejuni isolates from cold and frozen chickens using the RAPD-PCR technique with primers 1290 and HLWL, using the average of experiments with a tolerance of 1.5\% and UPGMA method with optimization of $80 \%$, by the program GelCompar. 
that form the K group obtained as standard the presence of transcripts for $c i a B$, dnaJ and $p 19$.

The dendrogram analysis of 19 strains of $C$. coli allowed the detection of three clusters identified by the profiles A, B and $\mathrm{C}$ and 12 distinct genotypes (Fig.2). These results also show the high level of genetic diversity among the isolates of this species.

The profile A was composed of strains from different states (Distrito Federal and Minas Gerais) and different flocks. The presence of a subgroup with $95.4 \%$ of homology was detected in the cluster B, which is composed of strains originating from the same flock provided from state of Goiás, suggesting that there is horizontal transmission of this genotype strain of chickens during primary processing or production. The other strain differs from the others, since it is provided from Minas Gerais and was collected in different date. A different pattern was found in the cluster C, where both strains were isolated from Minas Gerais, but in separate flocks. It is possible that the permanence of this genotype between consecutive flocks is a result of not meeting the standards of biosecurity from one flock to another.

In genotypic level, the clusters $A$ and $C$ presented transcripts for $\operatorname{sodB}$ in common. And the B subgroup showed no profile for transcripts of all the genes studied.

The genetic diversity observed by RAPD-PCR in $C$. jejuni and $C$. coli was also reported by Aquino et al. (2010), Madden et al. (2007), Ridley et al. (2008) and Workman et al. (2008) in Campylobacter isolates from chickens, pigs and medical patients in Brazil, United Kingdom and Barbados. This genotypic variation may be due to over exposure to a source of contamination during the production process of chickens, or genetic changes in bacterial population after colonization (Workman et al. 2008). Furthermore, Campylobacter spp. has a natural ability to change and undergo genomic rearrangements, which may also explain the higher genetic diversity (Ridley et al. 2008). Other reasons include the contamination of samples with multiple strains and cross-contamination (Workman et al. 2008).

The persistence of strains with high percentage of phylogenetic similarity in different flocks was also reported by Petersen \& Wedderkopp (2001) in chicken samples. The authors associated the problem of the lack of hygienic conditions and the presence of insects and rodents as indicative of the microorganism permanence in the production chain of chickens.

In this study, similar genealogical groups were found in the three regions studied, indicating a probable association of genotypes in different parts of the country. Evidence of highly similar strains circulating in the country and possibly in other countries may indicate that Campylobacter have the capacity to act in a widespread form, as a global transmission network in humans. This fact was also observed by Sheppard et al. (2010) who observed high similarity among isolates of the Netherlands, USA and Senegal, revealing the international diffusion of highly phylogenetically close lines.

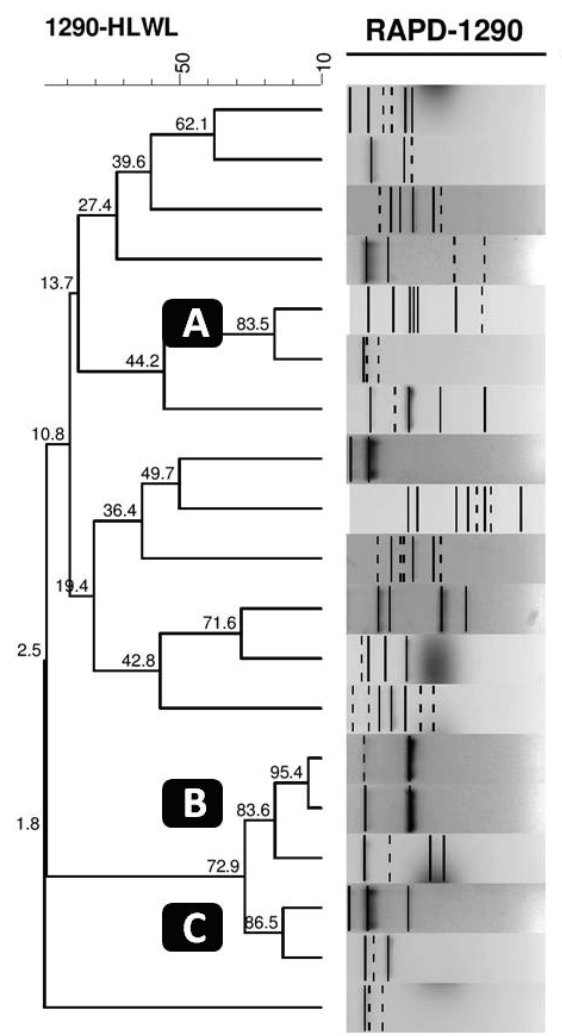

\section{RAPD-HLWL}

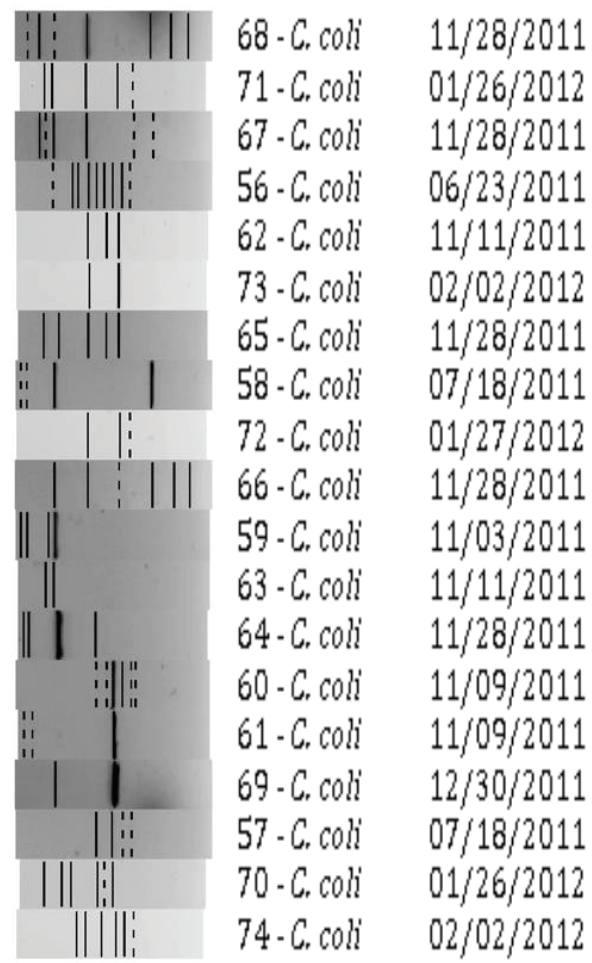

Fig.2. Dendrogram of the 19 isolates of Campylobacter coli coming from chilled and frozen chickens, the RAPD-PCR with the primers 1290 and HLWL, using the average from experiments with a tolerance of $1.5 \%$ and UPGMA method with optimization of $80 \%$ by GelCompar program. 


\section{CONCLUSIONS}

The percentages of isolation found in chicken carcasses indicate the potential risks to the consumer, since these are strains that have withstood the processing of slaughter, in addition to cooling or subsequent freezing. This reinforces the need to implement more stringent control programs.

Changes in gene transcription observed as the growing conditions of the microorganism demonstrated the capacity of Campylobacter to modulate their virulence, by changing its transcriptome. This variation shows that the agent is able to adapt to a condition imposed on it, sometimes to ensure their survival as in stressful situations, and sometimes to express their pathogenic potential as observed in cell cultures of human origin, directly related to symptoms and the development of clinical disease.

The genotypic diversity observed revealed that there are probably several sources of of poultry infection and contamination of carcasses during the production process.

Conflict of interest statement.- The authors declare that they have no conflicts of interest.

\section{REFERENCES}

Agunos A., Léger D., Avery B.P., Parmley E.J., Deckert A., Carson C.A. \& Dutil L. 2013. Ciprofloxacin resistent Campylobacter spp. in retail chicken, Western Canada. Emerg. Infect. Dis. 19(7):1121-1124.<http://dx.doi. org/10.3201/eid1907.111417><PMid:23764141>

Akopyanz N., Bukanov N.O., Westblom T.U., Kresovich S. \& Berg D.E. 1992. DNA diversity among clinical isolates of Helicobacter pylori detected by PCR-based RAPD fingerprinting. Nucleic Acids Res. 20(19):51375142. <http://dx.doi.org/10.1093/nar/20.19.5137><PMid:1408828>

Aquino M.H.C., Filgueiras A.L.L., Matos R., Santos K.R.N., Ferreira T., Ferreira M.C.S., Teixeira L.M. \& Tibana A. 2010. Diversity of Campylobacter jejuni and Campylobacter coli genotypes from human and animal sources from Rio de Janeiro, Brazil. Res. Vet. Sci. 88(2):214-217. <http://dx.doi. org/10.1016/j.rvsc.2009.08.005><PMid:19765787>

Birk T., Wik M.T., Lametsch R. \& Knochel S. 2012. Acid stress response and protein induction in Campylobacter jejuni isolates with different acid tolerance. BMC Microbiol. 12(1):174. <http://dx.doi.org/10.1186/14712180-12-174><PMid:22889088>

CDC 2013. Campylobacter. Division of Foodborne, Waterborne, and Environmental Diseases (DFWED), National Center for Emerging and Zoonotic Infectious Diseases (NCEZID), Center for Disease Control and Prevention (CDC). Available at <http://www.cdc.gov/nczved/ divisions/dfbmd/diseases/campylobacter/technical.html> Accessed on Apr. 2, 2014.

Di Giannatale E., Di Serafino G., Zilli K., Alessiani A., Sacchini L., Garofolo G., Aprea G. \& Marotta F. 2014. Characterization of antimicrobial resistance patterns and detection of virulence genes in Campylobacter isolates in Italy. Sensors, Basel 14(2):3308-3322. <http://dx.doi.org/10.3390/ s140203308> <PMid:24556669>

EFSA 2010. Analysis of the baseline survey on the prevalence of Campylobacter in broiler batches and of Campylobacter and Salmonella on broiler carcasses in the EU, 2010. EFSA J. 8(8):1-132.

EFSA 2013. The European Union summary report on trends and sources of zoonoses, zoonotic agents and food-borne outbreaks in 2011, 2013. EFSA J. 11(4):1-250.

EFSA 2014. The European Union summary report on trends and sources of zoonoses, zoonotic agents and food-borne outbreaks in 2012. EFSA J. 12(2):1-312. <http://dx.doi.org/10.2903/j.efsa.2014.3547>
FAO 2009. Risk assessment of Campylobacter spp. in broiler chickens: technical report. Microbiological Risk Assessment Series. Vol. 12. Food and Agriculture Organization of the United Nations, World Health Organization, Geneva, p.132.

Harmon K.M., Ransom G.M. \& Wesley I.V. 1997. Differentiation of Campylobacter jejuni and Campylobacter coli by polymerase chain reaction. Mol. Cell. Probes 11(3):195-200. <http://dx.doi.org/10.1006/ mcpr.1997.0104> <PMid:9232618>

ISO 2006. ISO 10272-1: Microbiology of food and animal feeding stuffs: horizontal method for detection and enumeration of Campylobacter spp. Part 1: Detection method. 2nd ed. International Standards Organization, Geneva.

Konkel M.E., Monteville M.R., Rivera-Amill V. \& Joens L.A. 2001. The pathogenesis of Campylobacter jejuni: mediated enteritis. Curr. Issues. Intest. Microbiol. 2(2):55-71. <PMid:11721281>

Konkel M.E., Klena J.D., Rivera-Amill V., Monteville M.R., Biswas D., Raphael B. \& Mickelson J. 2004. Secretion of virulence proteins from Campylobacter jejuni is dependent on a functional flagellar export apparatus. J. Bacteriol. 186(11):3296-3303.<http://dx.doi.org/10.1128/ JB.186.11.3296-3303.2004><PMid:15150214>

Li Y.P., Ingmer H., Madsen M. \& Bang D.D. 2008. Cytokine responses in primary chicken embryo intestinal cells infected with Campylobacter jejuni strains of human and chicken origin and the expression of bacterial virulence-associated genes. BMC Microbiol. 8(1):107. <http://dx.doi. org/10.1186/1471-2180-8-107><PMid:18588667>

Ma Y., Hanning I. \& Slavik M. 2009. Stress-induced adaptive tolerance response and virulence gene expression in Campylobacter jejuni. J. Food Safety 29(1):126-143. <http://dx.doi.org/10.1111/j.1745-4565.2008.00147.x>

Madden R.H., Moran L. \& Scates P. 2007. Diversity of Campylobacter coli genotypes in the lower porcine gastrointestinal tract at time of slaughter. Lett. Appl. Microbiol. 45(6):575-580. <http://dx.doi.org/10.1111/j.1472765X.2007.02246.x><PMid:17922816>

Melo R.T., Nalevaiko P.C., Mendonça E.P., Borges L.W., Fonseca B.B., Beletti M.E. \& Rossi D.A. 2013. Campylobacter jejuni strains isolated from chicken meat harbour several virulence factors and represent a potential risk to humans. Food Control 33(1):227-231. <http://dx.doi. org/10.1016/j.foodcont.2013.02.032>

Mourik A.V. 2011. Host adaptation mechanisms and transcriptional regulation in Campylobacter jejuni. Doctoral Dissertation, Infection and Immunity Center Utrecht, Universiteit Utrecht. 152p.

Palyada K., Threadgill D. \& Stintzi A. 2004. Iron acquisition and regulation in Campylobacter jejuni. J. Bacteriol. 186(14):4714-4729. <http:// dx.doi.org/10.1128/JB.186.14.4714-4729.2004> <PMid:15231804>

Petersen L. \& Wedderkopp A. 2001. Evidence that certain clones of Campylobacter jejuni persist during successive broiler flock rotations. Appl. Environ. Microbiol. 67(6):2739-2745. <http://dx.doi.org/10.1128/ AEM.67.6.2739-2745.2001><PMid:11375189>

Pinto M., Robine S. \& Appay M.D. 1983. Enterocyte-like differentiation and polarization of the human colon carcinoma cell line Caco-2 in culture. Biol. Cell 47:323-330.

Poly F. \& Guerry P. 2008. Pathogenesis of Campylobacter. Curr. Opin. Gastroenterol. 24(1):27-31. <http://dx.doi.org/10.1097/ MOG.0b013e3282f1dcb1><PMid:18043229>

Ridley A.M., Toszeghy M.J., Cawthraw S.A., Wassenaar T.M. \& Newell D.G. 2008. Genetic instability is associated with changes in the colonization potential of Campylobacter jejuni in the avian intestine. J. Appl. Microbiol. 105(1):95-104.<http://dx.doi.org/10.1111/j.1365-2672.2008.03759. $\mathrm{x}><$ PMid:18298527>

Sheppard S.K., Colles F., Richardson J., Cody A.J., Elson R., Lawson A., Brick G., Meldrum R., Little C.L., Owen R.J., Maiden M.C.J. \& McCarthy N.D. 2010. Host association of Campylobacter genotypes transcends geographic 
variation. Appl. Environ. Microbiol. 76(15):5269-5277.<http://dx.doi. org/10.1128/AEM.00124-10><PMid:20525862>

Stintzi A. 2003. Expression profile of Campylobacter jejuni in response to growth temperature variation. J. Bacteriol. 185(6):2009-2016.<http:// dx.doi.org/10.1128/JB.185.6.2009-2016.2003> <PMid:12618466>

Stintzi A. \& Whitworth L. 2003. Investigation of the Campylobacter jejuni cold-shock response by global transcript. Genome Lett. 2(1/2):18-27.

Thakur S., Zhao S., McDermott P.F., Harbottle H., Abbott J., English L., Gebreyes W.A. \& White D.G. 2010. Antimicrobial resistance, virulence, and genotypic profile comparison of Campylobacter jejuni and Campylobacter coli isolated from humans and retail meats. Foodborne Pathog. Dis. 7(7):835-844. <http://dx.doi.org/10.1089/fpd.2009.0487> $<$ PMid:20367499>

Workman S.N., Mathison G.E. \& Lavoie M.C. 2008. An investigation of sources of Campylobacter in a poultry production and packing operation in Barbados. Int. J. Food. Microbiol. 121(1):106-111. <http://dx.doi. $\operatorname{org} / 10.1016 /$ j.ijfoodmicro.2007.10.014> <PMid:18061296>
WHO 2013. The global view of campylobacteriosis. World Health Organization, Geneva. Available at <https://extranet.who.int/iris/ restricted/bitstream/10665/80751/1/9789241564601_eng.pdf> Accessed on Mar. 27, 2014.

Xie Y.P., He Y.P., Irwin P.L., Jin T. \& Shi X.M. 2011. Antibacterial activity and mechanism of action of zinc oxide nanoparticles against Campylobacter jejuni. Appl. Environ. Microbiol. 77(7):2325-2331. <http://dx.doi. org/10.1128/AEM.02149-10><PMid:21296935>

Zhao S., Young S.R., Tong E., Abbott J.W., Womack N., Friedman S.L. \& McDermott P.F. 2010. Antimicrobial resistance of Campylobacter isolates from retail meat in the United States between 2002 and 2007. Appl. Environ. Microbiol. 76(24):7949-7956. <http://dx.doi.org/10.1128/ AEM.01297-10><PMid:20971875>

Ziprin R.L., Young C.R., Byrd J.A., Stanker L.H., Hume M.E., Gray S.A., Kim B.J. \& Konkel M.E. 2001. Role of Campylobacter jejuni potential virulence genes in cecal colonization. Avian Dis. 45(3):549-557. <http://dx.doi. org/10.2307/1592894> <PMid:11569726> 